\title{
Performance Evaluation of Belt Type Seed Metering Mechanism
}

\author{
A.V. Gajakos ${ }^{1}$, S. H. Thakare ${ }^{2}$, A.K.Kamble ${ }^{3}$, S.K Thakare ${ }^{4}$, R.D.Walke ${ }^{5}$ \\ ${ }^{I}$ Senior Scientist, AICRP on FIM Dr. P.D.K.V, Akola. \\ ${ }^{2}$ Head, Department of FPM, Dr. P.D.K.V, Akola. \\ ${ }^{3} P I$, FMT \&TC, Deptt. of FPM, ,Dr. P. D. K.V., Akola \\ ${ }^{4}$ Associate Professor, Deptt. of FPM, Dr. P.D.K.V, Akola, \\ ${ }^{5}$ Associate Professor, CoA, Dr. P.D.K.V, Akola,
}

DOI: 10.46335/IJIES.2020.5.11.10

\begin{abstract}
Cotton (Gossypium spp.), popularly called as "White gold" is one of the most important commercially grown crop in India. India ranks first in area of cultivation and third in cotton production. The planting cotton seed is one of the critical tasks due to high labour requirement (15\%) thus, it results in higher cost of cultivation. The dibbling of cotton seeds is mostly done by women labors in squatting posture which makes this operation laborious and drudgerious. In case of rainfed agriculture, the sowing operation need to be perform in short time period that creates high demand of labors during peak sowing season and the obvious labor shortages, resulting in higher demand of wages by the labor. Presently the tractor operated precision pneumatic planter is the only option available for precise metering of the seed but high initial cost, un-availability of trained manpower, repair and service facilities set limit in its use. Thus in-order to tackle the problem in planting of seed cotton present research entitled "Development and performance evaluation of belt type precision seed metering mechanism" was undertaken. The developed seed metering mechanism was evaluated in laboratory at different forward speed (2.5, 3 and $\left.3.5 \mathrm{kmh}^{-1}\right)$ and seed belt inclination angle $\left(17^{\circ}, 34^{\circ}\right.$ and $\left.45^{\circ}\right)$ and found that at forward speed of $3.0 \mathrm{kmh}^{-1}$ and seed belt inclination angle of $34^{\circ}$, the developed belt type seed metering mechanism gave better performance in terms of missing index, multiple index, quality feed index and uniformity index.
\end{abstract}

Keywords- Metering mechanism, missing index, multiple index, uniformity index etc.

\section{I- INTRODUCTION}

C otton (Gossypium spp.), the "King of fiber" is one of the most important crops commercially grown in the world. In India, cotton is cultivated in an area of about 8.06 mha with a production potential of 23.2 million bales). India ranks first in area of cultivation and third (next to USA and China) in production of cotton. Maharashtra is the largest cotton growing state in the country. It covers about $34 \%$ of total cotton area and contributes $17 \%$ of the production (Sadanshiv et. al. 2017). Maharashtra has nearly one third of national cotton area and about 3 million farmers are engaged in cotton cultivation. In Vidarbha region, cotton is the most important cash crop grown on an area of $1.5 \mathrm{mha}$ with production of 2.7 million bales of cotton. In Vidarbha region the productivity of cotton is low (350 $\left.\mathrm{kgha}^{-1}\right)$ as compared to national $\left(502 \mathrm{kgha}^{-1}\right)$ (Sadanshiv et. al. 2017). The planting cotton seed is one of the critical tasks as it involve high labour requirement $(15 \%)$ which is next to harvesting operation (44\%)(Reference). Thus, it results in higher cost of cultivation. Due to high cost of Bt. Cotton seed, planting of cotton seed mainly performed by woman labors in squatting posture which makes this operation more laborious and drudgerious. In case of rainfed agriculture, to complete the sowing operation in limited time period is of great importance for further proper crop growth. This creates high demand of labors during peak 
sowing season and the obvious labor shortages, resulting in higher demand of wages by the labor.

Precision planting is proper placement of seeds in row at desired depth and equal intervals. Precision planting saves seeds, utilize fertilizer to the best advantage and increase yield by enabling good cultivation practices. This technique results in uniform plant spacing, depth and aids for further mechanization of intercultural and farming operations that reduces the total cost of cultivation. Presently the tractor operated precision pneumatic planter is the only option available for precise metering of the seed. But high initial cost (minimum about Rs. 4 to 5 lakh per planter) lack of repair and maintenance facility and unavailability of skilled man power set limits for its use. In view of above constraints present research work entitled development and performance evaluation of belt type precision seed metering mechanism was under taken.

\section{II-MATERIAL AND METHODS}

\section{Belt type seed metering mechanism}

It consist of hopper, seed metering mechanism i.e. belt conveyor, seed tube and furrow opener as main functional component. There is no mechanical device is used as cutoff device to prevent the excess seeds from going to seed tube. Instead by using the dynamic angle of repose property of cotton seed, the extra seed carried on the seed belt surface was rolled down naturally back in the seed hopper again. This prevented the seed from getting any kind of mechanical injury. Only seed caught in the seed cell made on the seed belt, dropped in the seed tube. Hence seed metering mechanism gave good performance. The belt type seed metering mechanism is shown in fig.1.

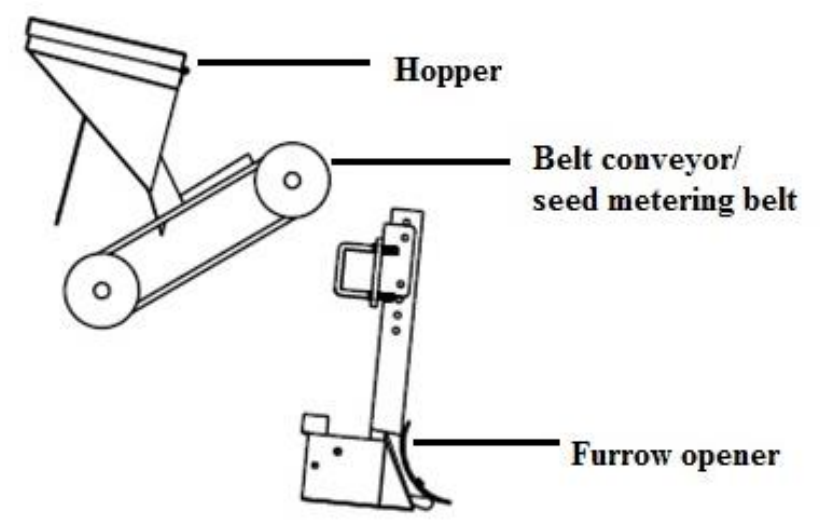

Figl. Belt type seed metering mechanism

\section{Laboratory setup}

For achieving the good performance of the seed metering mechanism from precise seed metering point of view, the forward speed and seed metering belt inclination angle are the very important aspects whose effect on performance parameters needed to be studied. Accordingly to study the sticky belt set was developed and the developed seed metering mechanism was tested for different combinations of forward speed and seed metering belt inclination angles and their effect on missing index, multiple index, quality feed index and uniformity feed index were observed.

Missing index- Missing index is an indicator of how often a seed skips the desired spacing. It is define as the percentage of spacing greater than 1.5 times the theoretical spacing. Smaller values of MI indicate better performance.

$$
\mathrm{MI}=\left(\mathrm{N}_{1} / \mathrm{N}\right) \times 100
$$

Where,

$$
\begin{aligned}
& \mathrm{N}=\text { Total number of observations, and } \\
& \mathrm{N}_{1}=\text { Number of spacing's in the region } \\
& >1.5 \text { times of the theoretical } \\
& \text { spacing }
\end{aligned}
$$

Multiple Index (DI)- Multiples are created when more than one seed is delivered by a cell. is the percentage of spacing that are less than or equal to half of the theoretical spacing. Smaller values of DI indicate better performance.

$$
\mathrm{DI}=\left(\mathrm{N}_{2} / \mathrm{N}\right) \times 100
$$

Where,

$$
\begin{aligned}
& \mathrm{N}=\text { Total number of observations, and } \\
& \mathrm{N}_{2}=\text { No. of spacing's in the region less than or } \\
& \text { equal to } 0.5 \text { times of the theoretical } \\
& \text { spacing }
\end{aligned}
$$

Quality of feed index- Quality of feed index (A) is the measure of how often the seed spacing's were close to the theoretical spacing. It is the percentage of spacing's that are more than half, but not more than 1.5 times the theoretical spacing (Bakhtiari and Loghavi, 2009).

$$
A=\left(\mathrm{N}_{3} / \mathrm{N}\right) \times 100
$$

Where,

$$
\begin{aligned}
& \mathrm{N}=\text { Total number of observations } \\
& \mathrm{N}_{3}=\text { Number of spacing's between } 0.5 \text { times the } \\
& \text { theoretical spacing and } 1.5 \text { times of the } \\
& \text { theoretical spacing }
\end{aligned}
$$

Uniformity index- Uniformity of spacing is the index of planting in any seeding operation. The parameters commonly used to express this uniformity are the coefficient of variance (CV) of the spacing between successive seed pieces. The standard deviation, mean and coefficient of variance of seed spacing will be calculated for uniformity index (Ashok kumar et. al. 2012).

Where,

$$
\mathrm{UI}=(1-\mathrm{CV}) X 100
$$

$\mathrm{CV}=$ Coefficient of variance, 


\section{Treatment details}

The laboratory trials were conducted as per treatment combinations shown in table 1 and the effect of independent parameters on dependent parameters were studied.

Table 1 Design of experiment for evaluation of belt type seed metering mechanism

\begin{tabular}{|l|l|l|}
\hline \multicolumn{1}{|c|}{ Independent parameters } & \multicolumn{1}{|c|}{ Levels } & \multicolumn{1}{c|}{ Dependent parameters, \% } \\
\hline Forward speed, $\mathrm{kmh}^{-1}$ & $2.5,3,3.5$ & 1. Missing index \\
Seed belt inclination angle, & $17,34,45$ & 2. Multiple index, \\
degree & & $\begin{array}{l}\text { 3.Quality feed index and } \\
\text { 4.Uniformity feed index }\end{array}$ \\
\hline
\end{tabular}

III- RESULT AND DISCUSSIONS

Results of the laboratory trials are presented in table no.2.

Table 2- Test results of Laboratory trials (PKV Hy-2 BGII)

\begin{tabular}{|c|c|c|c|c|c|}
\hline \multirow[t]{2}{*}{ Sr.no. } & \multirow[t]{2}{*}{ Parameter } & \multirow{2}{*}{$\begin{array}{c}\text { Forward } \\
\text { speed, km/h }\end{array}$} & \multicolumn{3}{|c|}{ Seed belt inclination angle } \\
\hline & & & $17^{0}$ & $34^{0}$ & $45^{0}$ \\
\hline \multirow[t]{3}{*}{1} & \multirow[t]{3}{*}{ Missing index } & 2.5 & 10.00 & 6.66 & 5.33 \\
\hline & & 3.0 & 6.66 & 2.66 & 8.66 \\
\hline & & 3.5 & 10.00 & 7.33 & 18.00 \\
\hline \multirow[t]{3}{*}{2} & \multirow[t]{3}{*}{ Multiple index } & 2.5 & 28.00 & 20.00 & 10.00 \\
\hline & & 3.0 & 14.00 & 5.33 & 5.33 \\
\hline & & 3.5 & 15.33 & 10.00 & 8.66 \\
\hline \multirow[t]{3}{*}{3} & \multirow[t]{3}{*}{ Quality feed index } & 2.5 & 62.00 & 72.33 & 84.66 \\
\hline & & 3.0 & 79.33 & 90.66 & 86.00 \\
\hline & & 3.5 & 74.66 & 82.66 & 76.00 \\
\hline \multirow[t]{3}{*}{4} & \multirow{3}{*}{$\begin{array}{ll}\text { Uniformity } & \text { feed } \\
\text { index } & \end{array}$} & 2.5 & 49.37 & 48.30 & 64.70 \\
\hline & & 3.0 & 59.76 & 76.46 & 67.46 \\
\hline & & 3.5 & 55.06 & 64.46 & 60.56 \\
\hline
\end{tabular}

Based on the results (Table 2) of the laboratory trials conducted, the highest missing index (i.e. $18.00 \%$ ) was found at $3.5 \mathrm{kmh}^{-1}$ operating speed and the $45^{0}$ seed belt inclination angle and lowest (i.e. $2.66 \%$ ) at the $3.0 \mathrm{kmh}^{-1}$ operating speed and $34^{\circ}$ seed belt inclination angle. Similarly, the highest multiple index (i.e. $28.00 \%$ ) was found at $2.5 \mathrm{kmh}^{-1}$ operating speed and the $17^{0}$ seed belt inclination angle and lowest (i.e. $5.33 \%$ ) at the $3.0 \mathrm{kmh}^{-1}$ operating speed and $34^{\circ}$ and $45^{\circ}$ seed belt inclination angle. The maximum quality feed index and uniformity feed index obtained at the $3.0 \mathrm{kmh}^{-1}$ operating speed and $34^{0}$ and lowest at $2.5 \mathrm{kmh}^{-1}$ operating speed and the $17^{0}$ seed belt inclination angle. It was also observed that the cells made on the seed belt picked up the single seed from the seed hopper and delivered it into the seed tube.

\section{IV-SUMMERY AND CONCLUSIONS}

Based on the laboratory evaluations following conclusions were drawn.

1. From the laboratory trials conducted it was found that at forward speed of $3.0 \mathrm{kmh}^{-1}$ speed and seed
2. belt inclination angle of $34^{0}$, the developed belt type seed metering mechanism gave better performance in terms of missing index, multiple index, quality feed index and uniformity index.

3. The missing index was highest at highest angle of seed belt inclination $\left(45^{\circ}\right)$ and highest forward speed $\left(3.5 \mathrm{kmh}^{-1}\right)$. Multiple Index was highest at lowest forward speed $\left(2.5 \mathrm{kmh}^{-1}\right)$ and lowest angle of seed belt inclination $\left(17^{0}\right)$.

4. Both the missing index and multiple index was lowest at the $3.0 \mathrm{kmh}^{-1}$ and $34^{0}$ combination of forward speed and seed belt inclination angle combination.

5. The quality feed index was lowest at lowest forward speed and lowest angle of seed belt inclination i.e. $2.5 \mathrm{kmh}^{-1}$ and $17^{0}$ respectively. Whereas it was highest at $3 \mathrm{kmh}^{-1}$ and $34^{0}$ combination of forward speed and seed belt inclination angle combination.

6. The uniformity index was lowest at lowest forward speed $\left(2.5 \mathrm{kmh}^{-1}\right)$ but at $34^{0}$ seed belt 
inclination. It was found maximum at $3.0 \mathrm{~km} / \mathrm{h}$ forward speed and $34^{0}$ inclination of seed belt.

\section{REFERENCES}

[1] Adalinge NB, Ghune GP, Lavate GB and Mane RR (2017). Design and manufacturing of seed sowing machine. International Journal of Advance Research Ideas and Innovations in Tech. (3):2.

[2] Adekanye,Timothy Adesoye, Akande andAvoyunafa Mary (2015). Development and evaluation of a manual multi crop planter for peasant farmers. Elixir Agriculture 86: 35095-35101.

[3] Al-Hamed SA, Wahby MF, AbdulwahedMA and Tabash IS(2015). Evaluating a laboratory test-rig for calibration of a grain drill for educational purpose, ARPN J. of Agri. and Biological Sci. (10):12.

[4] Anand G, (2016).Rohinish K, Gursahib Singh Manes, Dixit $A$ and Verma A Development and evaluation of inclined plate metering mechanism for onion pelleted seeds.Vegetos- An International Journal of Plant Research. 29:3.

[5] Bainer, R., R. A. Kepner and E. L. Barger, 1960. Principles of Farm Machinery. John Wiley and sons, Inc,. Newyork.

[6] Bakhtiari, M. R., and M. Loghavi, 2009. Development and evaluation of an innovative garlic clove precision planter. J. Agric. Sci. Technol.11: 125-136.

[7] Cotton history. In factsanddetails.com. Retrieved Juley 28, 2019,fromhttp://factsanddetails.com/world/cat54/sub349/i tem1227.html.

[8] Cotton production in world 2049. In cotton outlook. Retrieved Juley 28, 2019, from http://agricoop.nic.in/allindia-crop-situation.

[9] Duanyang G, Ruicheng D, Daoli Z and Dan L(2013). Experimental research on belt type of precision seedmetering device, Advanced Materials Research ISSN: 712715:1339-1342.

[10] Important of cotton in economics.In COTAAP. Retrieved Juley 28, 2019, from https://wcrc.confex.com /wcrc /2007/techprogram/P1780.HTM.

[11] Indian agriculture background information. In Wikipedia. Retrieved Juley 28, 2019, from https://en.wikipedia.org /wiki/Agriculture_in_India.

[12] Ismail ZE (2015). Seeder equipped with seeds delivery mechanism depending on an oscillating motivation unit, MisrJ. Ag. Eng. 32(4):1761-1774.

[13] Kamaraj $P$ and Kathirve P(2008). Development and evaluation of tractor operated belt type cotton planter,Journal of Agricultural Engineering 45(1).
[14] Kamble AK, Rahate RH, Deogirikar AA, Diwane LP, and Arulkar KP(2003). Development and evaluation of multipower operated cotton planter.Bioved,14(1,2): 29 32.

[15] Kankal US, Karale DS, Khambalkar VP and Thakare SH(2015). Performance evaluation of sigle row manual cotton planter. International Journal of Agricultural Engineering. 9 (1): 19-26.

[16] Sadanshiv N S, Wagh N.S. and Thelka SI. (2017). Characterization of selected cotton growing soils of Wardha district, Maharashtra. An Asian Journal of Soil Scienc. e ISSN- 0976-7231. Vol 12 (1), 174-180.

[17] Thakare SH, Kadam DM and Saraf VV (2014). Performance evaluation of bullock drawn cotton planter.International Journal of Agricultural Engineering. 7 (2): 442-445. 